\title{
Zooplankton diversity of drainage system reservoirs at an opencast mine
}

\author{
Anna Maria Goździejewska*, Andrzej Robert Skrzypczak, Ewa Paturej and Jacek Koszałka \\ Department of Tourism, Recreation and Ecology, University of Warmia and Mazury in Olsztyn, Oczapowskiego Str. 5, \\ 10719 Olsztyn, Poland
}

\begin{abstract}
The aim of this study was to determine the structure of zooplankton in three artificial water reservoirs, the technological function of which is to pre-treat waters from a drainage system of a brown coal open mine by removing inorganic suspension. The background for the zooplankton qualitative and quantitative analyses was the hydrochemical conditions in the individual reservoirs. The greatest zooplankton abundance $(N)$, number of taxa $(n)$, Shannon's diversity $\left(H^{\prime}\right)$, and species eveness $\left(J^{\prime}\right)$ was noted in reservoir Chabielice $\left(N_{\text {mean }}=1311\right.$ ind. $\left.\mathrm{L}^{-1}, n=26, H^{\prime}=2.09, J^{\prime}=0.64\right)$ which was dominated by eurytopic Rotifera species (Keratella cochlearis, Keratella tecta, Keratella valga, Polyarthra longiremis, Filinia longiseta). Their abundance was positively correlated with water $\mathrm{pH}$ and nutrient concentrations. Reservoir Kamień was characterized by the highest mean values of total suspension $\left(9.6 \mathrm{mg} \mathrm{L}^{-1}\right)$, chlorophyll $a(\mathrm{Chl} a)$ content $\left(10.4 \mu \mathrm{g} \mathrm{L}^{-1}\right)$, and water temperature $\left(20.0^{\circ} \mathrm{C}\right)$. These factors significantly correlated with crustacean biomass. The thermal-oxygenation conditions, low trophic level, and low productivity of the water $\left(\mathrm{Chl} a=5.4 \mu \mathrm{g} \mathrm{L}^{-1}\right)$ in reservoir Północny determined the overall low zooplankton abundance $\left(N_{\text {mean }}=153\right.$ ind. $\left.\mathrm{L}^{-1}\right)$. Artificial water bodies of opencast mine drainage systems are biologically unstable, but they do have some characteristics of natural ecosystems, and they do take over their functions. Zooplankton is an indicator of their ecological functionality. Knowledge gained about such reservoirs could contribute to decision-making about strategies for water reclamation and how to manage it.
\end{abstract}

Keywords: biodiversity / Rotifera / crustacea / hydrochemisty / brown coal opencast mining

Résumé - Diversité zooplanctonique des réservoirs du système de drainage d'une mine à ciel ouvert. L'objectif de cette étude était de déterminer la structure du zooplancton dans trois réservoirs d'eau artificiels, dont la fonction technologique est de prétraiter les eaux d'un système de drainage d'une mine à ciel ouvert de lignite en éliminant la suspension inorganique. Les analyses qualitatives et quantitatives du zooplancton se fondent sur les conditions hydrochimiques dans les différents réservoirs. La plus grande abondance du zooplancton $(N)$, le nombre de taxons $(n)$, la diversité de Shannon $\left(H^{\prime}\right)$ et l'uniformité des espèces $(J)$ a été trouvée dans le réservoir Chabielice $\left(N_{\text {mean }}=1311\right.$ ind. $\left.\mathrm{L}^{-1}, n=26, H^{\prime}=2.09, J^{\prime}=0.64\right)$ qui était dominé par des espèces de rotifères eurytopiques (Keratella cochlearis, Keratella tecta, Keratella valga, Polyarthra longiremis, Filinia longiseta). Leur abondance était corrélée positivement avec le pH de l'eau et les concentrations en nutriments. Le réservoir Kamień a été caractérisé par les valeurs moyennes les plus élevées de la suspension totale $\left(9,6 \mathrm{mg} \mathrm{L}^{-1}\right)$, de la teneur en chlorophylle a (Chl a) $\left(10.4 \mu \mathrm{g} \mathrm{L}^{-1}\right)$ et de la température de l'eau $\left(20^{\circ} \mathrm{C}\right)$. Ces facteurs étaient en corrélation significative avec la biomasse des crustacés. Les conditions d'oxygénation et de température, le faible niveau trophique et la faible productivité de l'eau $\left(\mathrm{Chl} a=5.4 \mu \mathrm{g} \mathrm{L}^{-1}\right)$ dans le réservoir Północny ont déterminé la faible abondance globale du zooplancton $\left(N_{\text {mean }}=153\right.$ ind. $\left.\mathrm{L}^{-1}\right)$. Les plans d'eau artificiels des systèmes de drainage de mine à ciel ouvert sont biologiquement instables, mais ils présentent certaines caractéristiques des écosystèmes naturels et assument leurs fonctions. Le zooplancton est un indicateur de leur fonctionnalité écologique. Les connaissances acquises sur ces réservoirs pourraient contribuer à la prise de décisions sur les stratégies d'épuration de l'eau et sur la façon de la gérer.

Mots-clés : biodiversité / Rotifera / crustacea / hydrochimie / extraction à ciel ouvert de lignite

\footnotetext{
*Corresponding author: gozdzik@uwm.edu.pl
} 


\section{Introduction}

Open mining natural minerals has a dramatic impact on the soils, waters, and air in the vicinities of open mines, and these cause changes in both the social fabric and the natural landscape (Lapčík and Lapčíková, 2011). Apart from the easily discernible and immediate changes on the earth's surface, such as the disappearance of forests and human settlements, certain alterations are to be expected in some more distant future (Nixdorf et al., 2005). With time, as open mining areas undergo dewatering, groundwater levels decline. As a result, some natural surface water bodies dry up and certain dysfunctions appear in local hydrographic systems (Younger and Wolkersdorfer, 2004; Sloss, 2013). Possible reasons are the translocation of water courses or the construction of the drainage ditches and technological water tanks that are necessary for strip mines to function (Bian et al., 2010). Meanwhile, the creation of new watercourses and reservoirs that enable an open mine to operate can also be seen as some additional potential resource, which can be used for other purposes beside the primary one, for which they are formed (Stottmeister et al., 2002). This is secondary, but equally important, role of artificial water bodies in urbanized, industrial areas with high population densities, where these reservoirs can serve social and recreational purposes (Rzętała, 2008).

The origin of artificial reservoirs, sets of abiotic factors, and how reservoirs are used are key factors in the directions and rates of biological succession in such new ecosystems. The current use and status of water reservoirs, in turn, influence species composition and hydrobiont density (von Sperling and Grandcham, 2010; Merrix-Johnes et al., 2013; BielańskaGrajner et al., 2014; Pociecha and Bielańska-Grajner, 2015). When reservoirs serve technological functions and there are large-amplitude fluctuations in environmental parameters, it is difficult to achieve ecosystem biological stabilization.

Zooplankton play an important role in any aquatic ecosystem. They are one of the first links in the consumer chain. They participate in the cycling of matter and energy flux by eliminating plankton algal cells from water depths (Mayer et al., 1997; Dodson et al., 2000). In turn, they serve as food for all fish species at the early ontogenetic development stage (Kerfoot and Sih, 1987; Sutela and Huusko, 2000). Zooplankton are characterized by short life cycles and fast adaptation to environmental changes. They are sensitive indicators of environmental responses to various disruptions (pollution, water flow and level, thermal conditions, acidification, etc.) (Ferrari et al., 2015; Goździejewska et al., 2016; Pociecha et al., 2017). Zooplankton species composition and quantitative parameters reflect ongoing phenomena and processes in water bodies (Dodson et al., 2007; Rönicke et al., 2010, Goździejewska and Tucholski, 2011). For this reason, zooplankton communities are useful in comparative investigations, the bioindication of water ecosystems, and in predicting environmental status (Boix et al., 2008; Ejsmont-Karabin, 2012, 2013; Marszelewski et al., 2017).

Given the above, the research of zooplankton communities in relations to mine water bodies conditions was considered to be necessary. It was assumed that the structure of zooplankton is shaped under the influence of various abiotic factors in the tested reservoirs. To verify the hypothesis stated above, it was appropriate to obtain an answer to the question: How zooplankton can react on the various conditions of examined water bodies? It should be emphasized that this type of research on the structure of zooplankton in artificial reservoirs, the technological function of which is to pre-treat waters originating from the draining system of brown coal open mine by removing inorganic suspension were not carried before. They are crucial from the point of view of the importance of open pit mines in Europe and for general limnology.

\section{Material and methods}

\subsection{Research site}

The study was conducted at three artificial reservoirs, which are used for pre-treatment of waters originating from a system of dewatering in Poland's biggest brown coal stripe mine (Fig. 1). Their main function is to reduce suspended matter through sedimentation but they are also exploited for recreational fishing. Reservoir Chabielice $\left(\mathrm{CH} ; 51^{\circ} 15^{\prime} 58.9^{\prime \prime} \mathrm{N}\right.$, $19^{\circ} 06^{\prime} 24.3^{\prime \prime} \mathrm{E}$ ) is supplied with water from the draining system of Szczerców open pit (OM-S); reservoirs Kamień (KA; $51^{\circ} 15^{\prime} 18.9^{\prime \prime} \mathrm{N}, \quad 19^{\circ} 12^{\prime} 15.4^{\prime \prime} \mathrm{E}$ ) and Północny (PN; $\left.51^{\circ} 15^{\prime} 13.9^{\prime \prime} \mathrm{N}, 19^{\circ} 22^{\prime} 01.3^{\prime \prime} \mathrm{E}\right)$ are supplied with water from the Bełchatów opencast mining (OM-B; Fig. 1). The reservoirs receive waters from different depths of the draining system, mixed in changeable proportions. They are enclosed by embankments, with the crowns about $3.5 \mathrm{~m}$ wide and the slope ratio of 1:2. The embankments are overgrown with meadow vegetation and shrubs. The area of each reservoir is approximately $7.5-8.0 \mathrm{ha}$; the depth of the main basin is $2.2 \mathrm{~m}$, whereas total volume is $103000 \mathrm{~m}^{3}$. At the maximal permissible inflow of $1.8 \mathrm{~m}^{3} \mathrm{~s}^{-1}$, water retention time is approximately $16 \mathrm{~h}$.

The technical parameters of the three reservoirs are the same and each of them comprises three functional zones (Fig. 2). The inflow zone collects water from supplying channels and serves for gravitational sedimentation of the coarsest suspended matter fraction (zone A). Next, water flows through the overflow comb baffle and reaches the central zone (the main basin of the reservoirs) measuring $100 \times 400 \mathrm{~m}$ (zone B), where fine inorganic fractions are deposited and organic compounds are metabolized aerobically. Sedimentation concludes in the plant filter zone, which is $100 \mathrm{~m}$ long and approximately $0.25 \mathrm{~m}$ deep (zone C). The filter comprises the following species of macrophytes: Phragmites communis, Typha latifolia, Glyceria maxima, Phalaris arundinacea, Acorus calamus, Carex acutiformis, Mentha aquatica and Salix cinerea.

\subsection{Sampling and analytical procedure}

Zooplankton were sampled from July to September in 2012 and from June to September in 2013. The sampling sites were in the central part of the basin of each of the three reservoirs (KA, CH, PN). Samples were collected with a $5 \mathrm{~L}$ Ruttner sampler from a depth of approximately $1 \mathrm{~m}$ beneath the surface. The sampled material of $20 \mathrm{~L}$ was passed through a plankton net with a mesh size of $30 \mu \mathrm{m}$, preserved with Lugol's solution, and fixed in a $4 \%$ formalin solution. The zooplankton was identified under a Zeiss AXIO Imager microscope to the lowest possible taxonomic unit (with the 


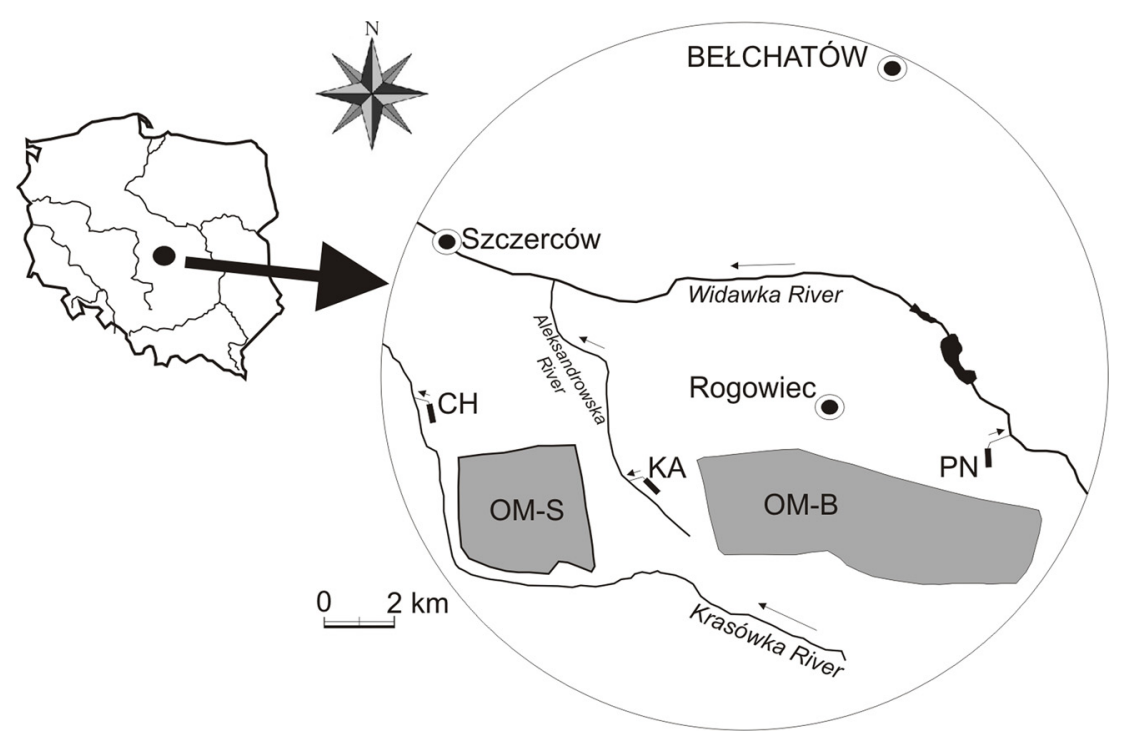

Fig. 1. Location of the study area. Abbreviations: OM-S - opencast mining Szczerców, OM-B - opencast mining Bełchatów; Reservoirs: CH - Chabielice, KA - Kamień, PN - Północny.

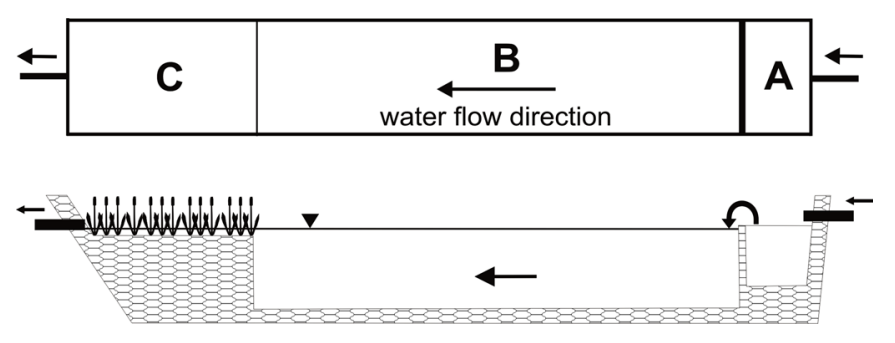

Fig. 2. Construction scheme of the reservoir. (A) The preliminary part with water overflow, (B) the main basin, (C) plant filter.

exception of Copepoda juvenile stages) using methods by von Flössner (1972); Koste (1978); Ejsmont-Karabin et al. (2004); Rybak and Błędzki (2010); and Błędzki and Rybak (2016). Quantitative analysis included determining zooplankton abundance using a Sedgewick-Rafter counting chamber. Zooplankton biomass was determined with methods by Ruttner-Kolisko (1977); Ejsmont-Karabin (1998); and Bottrell et al. (1976).

The dominance $(D)$ (Kasprzak and Niedbała, 1981), species richness (Margalef's index, $d$ ) and diversity (Shannon's index, $H^{\prime}$ ), and species evenness (Pielou's index, $J^{\prime}$ ) were analyzed. MVSP 3.22 software was used to analyze the taxonomic differentiation and similarity of the zooplankton communities (Bray-Curtis index) (Kovach, 2015).

The following physico-chemical parameters were analyzed at zooplankton sampling sites at each sampling event: temperature $\left(T,{ }^{\circ} \mathrm{C}\right)$, water $\mathrm{pH}$, Secchi disk transparency (SDT, m), water saturation (DO, $\mathrm{mg} \mathrm{L}^{-1}, \%$ ) and total dissolved solutions (TDS, $\mathrm{mg} \mathrm{L}^{-1}$ ). All physico-chemical parameters were measured using a YSI 6600 V2 MultiParameter Water Quality Sonde. Water samples were also collected during each sampling event for laboratory analyses of total nitrogen (TN), nitrate $\left(\mathrm{NO}_{3}{ }^{-}\right)$, total phosphorus (TP), orthophosphate $\left(\mathrm{PO}_{4}{ }^{3-}\right)$, and chlorophyll $a(\mathrm{Chl} a)$. The contents of total suspended matter, were also determined. The hydrochemical analyses were conducted in accordance with APHA guidelines (1999) (Tab. 1).

The trophic state index (TSI) of the analyzed reservoirs was calculated from the: Chl $a$, SDT, TP and TN (Carlson, 1977; Kratzer and Brezonik, 1981). The chemical composition of bottom sediments was also performed in order to obtain complete data of the hydrochemical conditions underlying the cycling of elements in the analyzed reservoirs.

\subsection{Statistical procedures}

Non-parametric analysis of variance was applied to assess the general differences in physicochemical indicators of water and in the quantitative parameters determined for the zooplankton among reservoirs, and major taxonomic groups (Statistica 13.0 for Windows, Statsoft, Tulsa). The results were processed with ANOVA and the non-parametric KruskalWallis test to determine statistically significant differences between reservoirs, in terms of physicochemical parameters of water and zooplankton structure $(H, P \leq 0.05)$. Correlation coefficients were calculated with the use of Spearmann ranks $(P \leq 0.05)$.

The response of zooplankton communities to the environmental variables was analysed with CANOCO 4.5 for Windows (ter Braak and Smilauer, 2002) using multivariate statistical procedures. Redundancy analysis (RDA) was used because the length of the gradient in the dataset checked in DCA ordination was CA $2.2 \mathrm{SD}$, which indicated a linear variation. RDA as direct gradient analysis was used to summarise the relationship between zooplankton species and environmental parameters. Redundant variables were removed by a step-wise regression (forward selection) with Monte Carlo permutation tests. The dataset was log transformed [log $(n+1)]$ and centred on species, as this is obligatory for the constrained linear methods.

RDA was performed for 21 zooplankton taxa and 2 larval stages of Copepoda (share $>2 \%$ ), and 10 environmental 
A.M. Goździejewska et al.: Knowl. Manag. Aquat. Ecosyst. 2018, 419, 33

Table 1. Physicochemical parameters and trophic indices for waters of the reservoirs (mean $\pm \mathrm{SD}$ ). Denotations: SDT - Secchi disk transparency, DO - dissolved oxygen, TDS - total dissolved solutions, Chl $a$ - chlorophyll $a, \mathrm{TP}$ - total phosphorus, TN - total nitrogen. Values with the different superscripts are significantly different among reservoirs by non-parametric Kruskal-Wallis test (ANOVA, $P \leq 0.05)$.

\begin{tabular}{|c|c|c|c|}
\hline Reservoir & $\mathrm{CH}$ & KA & PN \\
\hline \multicolumn{4}{|l|}{ Water parameters } \\
\hline Temperature $\left({ }^{\circ} \mathrm{C}\right)$ & $19.9 \pm 1.9$ & $20.0 \pm 2.7$ & $18.2 \pm 2.0$ \\
\hline $\operatorname{SDT}(\mathrm{m})$ & $0.71 \pm 0.13^{\mathrm{ab}}$ & $0.56 \pm 0.08^{\mathrm{a}}$ & $0.82 \pm 0.10^{\mathrm{b}}$ \\
\hline $\mathrm{pH}$ & $8.09 \pm 0.01^{\mathrm{a}}$ & $7.65 \pm 0.19^{b}$ & $7.55 \pm 0.17^{\mathrm{b}}$ \\
\hline $\mathrm{DO}\left(\mathrm{mg} \mathrm{L}^{-1}\right)$ & $8.15 \pm 0.45$ & $8.19 \pm 0.72$ & $9.22 \pm 1.08$ \\
\hline DO $(\%)$ & $83.7 \pm 0.4^{\mathrm{ab}}$ & $84.2 \pm 1.1^{\mathrm{a}}$ & $76.1 \pm 1.2^{\mathrm{b}}$ \\
\hline $\operatorname{TDS}\left(\mathrm{mg} \mathrm{L}^{-1}\right)$ & $595.8 \pm 116.9^{\mathrm{a}}$ & $672.5 \pm 78.9^{\mathrm{b}}$ & $588.0 \pm 39.2^{\mathrm{ab}}$ \\
\hline Total suspension $\left(\mathrm{mg} \mathrm{L}^{-1}\right)$ & $7.8 \pm 5.6^{\mathrm{ab}}$ & $9.6 \pm 5.8^{\mathrm{a}}$ & $4.0 \pm 2.1^{\mathrm{b}}$ \\
\hline Chl $a\left(\mu \mathrm{g} \mathrm{L}^{-1}\right)$ & $7.3 \pm 0.2^{\mathrm{ab}}$ & $10.4 \pm 6.2^{\mathrm{a}}$ & $5.4 \pm 1.4^{\mathrm{b}}$ \\
\hline $\mathrm{TP}\left(\mathrm{mg} \mathrm{L}^{-1}\right)$ & $0.231 \pm 0.138$ & $0.182 \pm 0.082$ & $0.104 \pm 0.033$ \\
\hline $\mathrm{PO}_{4}{ }^{3-}\left(\mathrm{mg} \mathrm{L}^{-1}\right)$ & $0.070 \pm 0.050$ & $0.022 \pm 0.010$ & $0.024 \pm 0.010$ \\
\hline $\mathrm{TN}\left(\mathrm{mg} \mathrm{L}^{-1}\right)$ & $0.468 \pm 0.091$ & $0.411 \pm 0.114$ & $0.383 \pm 0.132$ \\
\hline $\mathrm{NO}_{3}{ }^{-}\left(\mathrm{mg} \mathrm{L}^{-1}\right)$ & $0.180 \pm 0.026$ & $0.149 \pm 0.077$ & $0.173 \pm 0.058$ \\
\hline $\mathrm{N}_{\text {org }}\left(\mathrm{mg} \mathrm{L}^{-1}\right)$ & $0.193 \pm 0.120$ & $0.182 \pm 0.074$ & $0.139 \pm 0.108$ \\
\hline \multicolumn{4}{|l|}{ Trophic state parameters } \\
\hline TSI SDT & $65.06 \pm 2.53^{\mathrm{ab}}$ & $68.52 \pm 2.16^{\mathrm{a}}$ & $62.92 \pm 1.62^{\mathrm{b}}$ \\
\hline TSI Chl $a$ & $50.05 \pm 0.25$ & $52.52 \pm 4.90$ & $46.77 \pm 2.83$ \\
\hline TSI TP & $80.33 \pm 9.68^{\mathrm{a}}$ & $77.94 \pm 6.99^{\mathrm{ab}}$ & $70.51 \pm 4.71^{\mathrm{b}}$ \\
\hline TSI TN & $41.45 \pm 5.29^{\mathrm{ab}}$ & $38.47 \pm 2.02^{\mathrm{a}}$ & $44.49 \pm 1.44^{\mathrm{b}}$ \\
\hline
\end{tabular}

variables of water: temperature, $\mathrm{pH}, \mathrm{DO}$, total suspension, TDS and trophic variables $\left(\mathrm{TP}, \mathrm{PO}_{4}{ }^{3-}, \mathrm{TN}, \mathrm{NO}_{3}{ }^{-}, \mathrm{Chl} a\right)$. The nitrates $\left(\mathrm{NO}_{3}{ }^{-}\right)$and TDS parameters were excluded from the analysis because their variance inflation factors exceeded 20 .

\section{Results}

\subsection{Environmental characteristics}

The lowest water temperatures and the highest oxygenation were recorded in reservoir PN. The values of these characteristics were $16.6-21.1^{\circ} \mathrm{C}$ and $8.9-10.2 \mathrm{mg} \mathrm{O}_{2} \mathrm{~L}^{-1}$, respectively. In $\mathrm{CH}$ and $\mathrm{KA}$ these parameters were comparable and ranged from 18.4 to $24.1^{\circ} \mathrm{C}$ and from 7.2 to $8.8 \mathrm{mg} \mathrm{O}_{2} \mathrm{~L}^{-1}$ (Tab. 1). The greatest ranges of TP and TN concentrations were determined in reservoir $\mathrm{CH}\left(0.106-0.360 \mathrm{mg} \mathrm{L}^{-1}\right.$ and 0.350 $0.574 \mathrm{mg} \mathrm{L}^{-1}$, respectively). The mean contents of TP and the mean value of TSI TP was the lowest in reservoir PN $\left(\mathrm{TP}=0.103 \mathrm{mg} \mathrm{L}^{-1} ;\right.$ and TSI $\left.\mathrm{TP}=70.51\right)$, and differed significantly from the values reported in the $\mathrm{CH}$ The mean value of the TSI TN index was the highest in PN and differed from the value reported in the KA (Tab. 1).

The concentration of $\mathrm{Chl} a$ in reservoir KA ranged from 6.64 to $19.60 \mu \mathrm{g} \mathrm{L}^{-1}$ was significantly higher than that in reservoir PN; and was correlated with DO $(\% ; r=0.9856$, $P<0.05)$. The SDT in reservoir KA ranged from 0.4 to $0.65 \mathrm{~m}$ was significantly lower than that in reservoir PN $(0.8-1.1 \mathrm{~m})$. The mean value of TSI SDT index was the highest in the reservoir $\mathrm{KA}$, and was increasing proportionally to the concentration of total suspended matter $(r=0.544, P<0.05)$ and TDS $(r=0.790, P<0.05)$. The highest concentration of
TDS determined in reservoir KA, was significantly differ than in $\mathrm{CH}$ (Tab. 1).

Over $50 \%$ of the bottom sediment composition in all reservoirs consisted of silica. The reservoir PN was determined to contain the maximum concentrations of both, $\mathrm{SiO}_{2}(69.1 \%)$ and aluminium oxides (7.4\%). At the same time high concentration of the fractions $\mathrm{NaOH}-\mathrm{RP}=1.55 \mathrm{mg} \mathrm{P} \mathrm{d.m}$ and $\mathrm{TP}=3.97 \mathrm{mg} \mathrm{P} \mathrm{d. \textrm {m } ^ { - 1 }}$ was observed in bottom sediments in PN. The sediments in the $\mathrm{CH}$ and KA were distinguished by the highest share of organic matter and phosphorus fractions bound organic matter (Tab. 2). Physicochemical determinants of zooplankton community structure have been indicated by RDA and described in the discussion section.

\subsection{Zooplankton structure}

In the studied reservoirs, in total, 44 taxa of zooplankton were identified, including 34 Rotifera, 5 Cladocera and 5 Copepoda (Tab. 3). The total number of taxa was lowest in KA (21) and comparable in reservoirs $\mathrm{PN}$ and $\mathrm{CH}$ (27 and 26; Tab. 4). Rotifers were the most diverse group. The highest number of rotifer species were recorded in PN (23) and the lowest, in reservoir KA (12). Twenty rotifer species were identified in $\mathrm{CH}$.

The greatest ranges of zooplankton abundance and biomass were determined in reservoir $\mathrm{CH}$ (595-2462 ind. $\mathrm{L}^{-1}$ and $1.9-15.9 \mathrm{mg} \mathrm{L}^{-1}$, respectively), with high rotifers and crustaceans contribution (mean $73 \%$ and $70 \%$, respectively). The lowest ranges of zooplankton abundance and biomass were determined in reservoir PN (83-308 ind. $\mathrm{L}^{-1}$ and $0.03-$ $0.93 \mathrm{mg} \mathrm{L}^{-1}$, respectively), with the greatest contribution of rotifers (mean $93 \%$ and $76 \%$, respectively). The mean value of 
Table 2. Chemical composition of bottom sediments in the analyzed reservoirs in September 2012.

\begin{tabular}{|c|c|c|c|}
\hline Reservoir & $\mathrm{CH}$ & KA & $\mathrm{PN}$ \\
\hline \multicolumn{4}{|l|}{ Bottom sediments parameters $(\%)$} \\
\hline $\mathrm{CO}_{2}$ & 3.95 & 3.78 & 2.2 \\
\hline $\mathrm{SiO}_{2}$ & 51.68 & 59.45 & 69.06 \\
\hline $\mathrm{N}$ & 0.78 & 0.54 & 0.72 \\
\hline $\mathrm{CaO}$ & 3.56 & 3.92 & 3.1 \\
\hline $\mathrm{MgO}$ & 2.74 & 2.46 & 0.34 \\
\hline $\mathrm{Fe}_{2} \mathrm{O}_{3}$ & 4.99 & 4.37 & 3.98 \\
\hline $\mathrm{Al}_{2} \mathrm{O}_{3}$ & 3.42 & 2.99 & 7.41 \\
\hline Organic matter & 16.69 & 14.09 & 14.62 \\
\hline \multicolumn{4}{|l|}{ 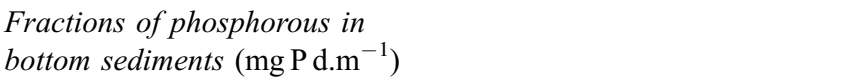 } \\
\hline $\mathrm{NH}_{4} \mathrm{Cl}-\mathrm{P}$ (labile) & 0.016 & 0.013 & 0.021 \\
\hline BD-P (bound Fe) & 0.188 & 0.251 & 0.378 \\
\hline $\mathrm{NaOH}-\mathrm{RP}$ (bound $\mathrm{Al}$ ) & 0.684 & 0.440 & 1.55 \\
\hline $\mathrm{NaOH}-\mathrm{NRP}$ (bound organic matter) & 0.99 & 1.039 & 0.857 \\
\hline HCl-P (bound Ca) & 0.484 & 0.530 & 0.522 \\
\hline Res-P & 0.612 & 0.610 & 0.637 \\
\hline TP & 2.87 & 3.23 & 3.97 \\
\hline
\end{tabular}

zooplankton density in reservoir PN was statistically differ among $\mathrm{CH} \quad(H=15.762, P<0.000$; Fig. 3A $)$; whereas zooplankton biomass in $\mathrm{PN}$ was differ than in $\mathrm{CH}$ and $\mathrm{KA}$ $(H=11.902, P<0.002$; Fig. 3B).

Species diversity and biocenotic relationships in the reservoirs were determined by the number of species and variations in the population size of each taxon. Average number of species was the highest in $\mathrm{CH}$ (17) and the lowest in KA (12; Fig. 3C). The zooplankton of reservoirs $\mathrm{CH}$ and $\mathrm{PN}$ was highly diverse $\left(H^{\prime}=2.09\right.$ and $2.01, d=6.72$ and 10.07, $J^{\prime}=0.640$ and 0.597 , respectively; Tab. 4). The zooplankton of KA was marked by the lowest values of diversity index $\left(H^{\prime}=1.67\right)$, richness and eveness index $(d=6.16$ and $\left.J^{\prime}=0.549\right)$. The differences in $H^{\prime}$ and $J^{\prime}$ indexes mean values between KA and the other two reservoirs, were significant (Fig. 3D-F). In reservoirs $\mathrm{CH}$ and KA, rotifer Polyarthra longiremis predominated $(40 \%$ and $43 \%$, respectively), followed by larval forms of copepods (19\% and 30\%, respectively); following species also dominated in these reservoirs: Keratella valga $(10 \% ; \mathrm{CH})$; Filinia longiseta $(5 \%$; $\mathrm{CH})$, Ascomorpha ovalis (10\%; KA), and cladoceran Daphnia cucullata $(9 \%$ and $6 \%$; KA and $\mathrm{CH})$. Reservoir PN was dominated by the rotifer taxa: P. longiremis (33\%), A. ovalis (27\%), Synchaeta spp. (12\%), Keratella tecta (9\%). The greatest faunal similarity between zooplankton communities was observed in KA and PN reservoirs by about $47 \%$. The PN was most different in this respect to $\mathrm{CH}(85 \%)$ (Tab. 5).

\subsection{Primary gradients affecting zooplankton community}

An overall RDA on zooplankton abundance incorporating the environmental variables with significant marginal effects showed that $78 \%$ of the variance was explained. The $\mathrm{pH}$ and DO had significant relationships $(P=0.002$ and $P=0.042$, respectively) with zooplankton, and they explained $34 \%$ and $15 \%$, respectively, of the variability (Fig. 4).

The sum of all the canonical eigenvalues was 0.867 (Tab. 6). The first two components of RDA explained $61.3 \%$ of the taxonomic variation, while the first axis accounted for $44.9 \%$ of total variance. This represents a $\mathrm{pH}$ gradient that is correlated negatively with DO. The second axis $(16.4 \%$ of total variance) was correlated with the chlorophyll $a$ gradient and negatively with concentration of $\mathrm{PO}_{4}{ }^{3-}$.

\section{Discussion}

Acidification, salinity, and pollution with mineral salts are the most frequent determinants of the biological conditions of post-mining waters (Bielańska-Grajner and Gładysz, 2010; Rönicke et al., 2010; Moser and Weisse, 2011; Bielańska-Grajner and Cudak, 2014; Ferrari et al., 2015; Sienkiewicz and Gąsiorowski, 2016; Pociecha et al., 2017). The physicochemical parameters of the analyzed reservoirs were similar to those of natural water bodies. The waters were slightly alkaline $(\mathrm{pH}=7.2-8.2)$, subsaline (TDS = 500-3000 $\mathrm{mg} \mathrm{L}^{-1}$; Hammer, 1993), and water conductivity ranged within $840-1005 \mu \mathrm{S} \mathrm{cm}^{-1}$. Thus, the hydrochemical water parameters were not a limiting factor in the development of most zooplankton species. The zooplankton richness in the examined reservoirs was shaped mainly by rotifers. The greatest Rotifer abundance and species diversity occurred in reservoir $\mathrm{CH}$. RDA analysis showed a strong positive correlation of the dominant species (K. tecta, P. longiremis, Keratella quadrata, Brachionus angularis, Brachionus calyciflorus, $F$. longiseta) with $\mathrm{pH}, \mathrm{PO}_{4}{ }^{3-}$ and TP, and TN (Figs. 4 and 5). These common pelagic species are most often identified in the Rotifera composition of artificial waters bodies (Balvert et al., 2009; Bielańska-Grajner and Gładysz, 2010; Mallo et al., 2010; Skowronek et al., 2012; Marszelewski et al., 2017; Pociecha et al., 2017). They are also thought to be indicative of water eutrophication (Ejsmont-Karabin, 2012). In the reservoirs analyzed, the concentration of chlorophyll $a$ (TSI Chla<60) indicated meso-eutrophic conditions, while the phosphorus content (TSI TP $>60$ ) indicated eu-hypertrophy (Carlson, 1977). Good trophic conditions in reservoirs $\mathrm{CH}$ and KA were confirmed by the constant presence of Cladocera. D. cucullata and Bosmina longirostris were the most numerous representatives of mature crustacean forms. RDA analysis showed that factors most positively correlated with incidence of mature and juvenile cladocerans and copepods were characteristic for reservoir KA; these were water temperature, chlorophyll $a$ concentrations, and total suspensions (Figs. 4 and 5). The high concentration of suspended matter could have been caused by the type of water supply and the resuspension of bottom sediments perhaps because of intense turbulence caused by water flow or the mechanical impact of wind. Moreover, the bottom sediments in reservoir KA were rich in organic bonds of phosphorus, which were regularly activated this way, entered circulation, and were promptly mineralized in the water column because of good oxygenation. This process could shape the intensity of primary production measured with chlorophyll $a$ and increase the biomass of crustacean zooplankton. Populations of large and 
A.M. Goździejewska et al.: Knowl. Manag. Aquat. Ecosyst. 2018, 419, 33

Table 3. Qualitative and quantitative structure of zooplankton based on dominating and frequent taxa in the individual reservoirs (mean \pm SD).

\begin{tabular}{|c|c|c|c|c|c|c|}
\hline \multirow[t]{2}{*}{ Taxa } & \multicolumn{2}{|c|}{$\mathrm{CH}$} & \multicolumn{2}{|c|}{ KA } & \multicolumn{2}{|c|}{$\mathrm{PN}$} \\
\hline & Mean & $\pm \mathrm{SD}$ & Mean & $\pm \mathrm{SD}$ & Mean & $\pm \mathrm{SD}$ \\
\hline Rotifera (ind. $\mathrm{L}^{-1}$ ) & 926 & 587 & 255 & 160 & 146 & 95 \\
\hline Ascomorpha ovalis (Bergendal, 1892) & & & $46^{* *}$ & 42 & $41^{* *}$ & 33 \\
\hline Asplanchna priodonta Gosse, 1850 & 12 & 18 & 1 & 1 & 5 & 5 \\
\hline Brachionus angularis Gosse, 1851 & 6 & 5 & & & $<1$ & 0 \\
\hline Brachionus calyciflorus Pallas, 1766 & 12 & 21 & & & & \\
\hline Brachionus spp. & & & & & 1 & 1 \\
\hline Colurella spp. & $<1$ & 0 & & & $<1$ & 0 \\
\hline Filinia longiseta (Ehrenberg, 1834) & $68^{*}$ & 56 & & & $<1$ & 0 \\
\hline Hexarthra mira (Hudson, 1871) & 12 & 13 & 2 & 3 & & \\
\hline Keratella cochlearis (Gosse, 1851) & 42 & 25 & 1 & 1 & 1 & 1 \\
\hline Keratella quadrata (Müller, 1786) & 4 & 4 & & & & \\
\hline Keratella tecta (Gosse, 1851) & 48 & 47 & & & $14^{*}$ & 20 \\
\hline Keratella valga (Ehrenberg, 1834) & $130^{*}$ & 71 & 1 & 1 & 1 & 1 \\
\hline Lecane spp. & 1 & 1 & 1 & 1 & & \\
\hline Lepadella ovalis (Müller, 1786) & $<1$ & 0 & & & $<1$ & 0 \\
\hline Notholca acuminata (Ehrenberg, 1832) & & & & & 2 & 2 \\
\hline Notholca squamula (Müller, 1786) & & & & & 3 & 2 \\
\hline Polyarthra longiremis Carlin, 1943 & $526^{* *}$ & 495 & $193^{* *}$ & 186 & $50^{* *}$ & 62 \\
\hline Polyarthra vulgaris Carlin, 1943 & 43 & 45 & & & & \\
\hline Pompholyx sulcata Hudson, 1885 & 10 & 11 & 7 & 7 & 6 & 5 \\
\hline Synchaeta sp. & 11 & 12 & 3 & 3 & $18^{* *}$ & 30 \\
\hline Testudinella patina (Herman, 1783) & & & & & 1 & 1 \\
\hline Trichocerca similis (Wierzejski, 1893) & & & & & 1 & 1 \\
\hline Rotifera other species & 1 & 1 & & & 2 & 1 \\
\hline Cladocera (ind. $\mathrm{L}^{-1}$ ) & 116 & 125 & 43 & 31 & 3 & 4 \\
\hline Coronatella rectangula Sars, 1861 & & & $<1$ & 0 & & \\
\hline Bosmina longirostris (Schoedler, 1866) & 31 & 49 & 3 & 2 & 2 & 2 \\
\hline Daphnia cucullata Sars, 1862 & $85^{*}$ & 85 & $39^{*}$ & 32 & 1 & 2 \\
\hline Diaphanosoma brachyurum (Liévin, 1848) & & & $<1$ & 0 & & \\
\hline Leptodora kindtii (Focke, 1844) & & & 1 & 1 & & \\
\hline Copepoda (ind. $\mathrm{L}^{-1}$ ) & 269 & 233 & 144 & 129 & 4 & 3 \\
\hline Cryptocyclops bicolor (Sars, 1863) & & & 3 & 3 & & \\
\hline Cyclops strenuus Fischer, 1851 & $<1$ & 0 & 1 & 1 & & \\
\hline Eucyclops speratus (Lilljeborg, 1901) & & & & & $<1$ & 0 \\
\hline Thermocyclops crassus (Fischer, 1853) & 7 & 9 & 5 & 7 & & \\
\hline Harpacticoida & 7 & 12 & 1 & 2 & $<1$ & 0 \\
\hline copepodites & $112^{*}$ & 68 & $40^{*}$ & 42 & 1 & 1 \\
\hline nauplii & $143^{* *}$ & 144 & $94^{* *}$ & 71 & 3 & 2 \\
\hline Number of species (ind.) & 17 & 1 & 12 & 3 & 14 & 5 \\
\hline Abundance of zooplankton (ind. $\mathrm{L}^{-1}$ ) & 1311 & 945 & 442 & 319 & 153 & 103 \\
\hline Rotifera $(\%)$ & 73.1 & 23.1 & 59.4 & 28.0 & 93.3 & 5.6 \\
\hline Cladocera $(\%)$ & 7.5 & 10.4 & 8.9 & 3.6 & 2.9 & 3.8 \\
\hline Copepoda $(\%)$ & 19.4 & 14.5 & 31.7 & 25.4 & 3.8 & 2.4 \\
\hline Biomass of zooplankton $\left(\mathrm{mg} \mathrm{L}^{-1}\right)$ & 10.32 & 11.1 & 4.95 & 4.47 & 0.34 & 0.40 \\
\hline Rotifera $(\%)$ & 30.3 & 37.3 & 8.4 & 10.3 & 75.7 & 20.9 \\
\hline Cladocera $(\%)$ & 55.2 & 37.9 & 73.2 & 25.0 & 15.1 & 22.9 \\
\hline Copepoda $(\%)$ & 14.6 & 9.1 & 18.4 & 16.1 & 9.2 & 12.8 \\
\hline
\end{tabular}

** - eudominant $(\geq 10 \%), *$ - dominant $(5-9.9 \%)$. 
Table 4. Measures of zooplankton quantitative and qualitative structure in individual.

\begin{tabular}{lccc}
\hline Parameter & CH & KA & PN \\
\hline Number of species (ind.) & 26 & 21 & 27 \\
Shannon's index, $H^{\prime}$ & 2.09 & 1.67 & 2.01 \\
Margalef's index, $d$ & 6.72 & 6.16 & 10.07 \\
Pielou's index, $J^{\prime}$ & 0.640 & 0.549 & 0.597 \\
\hline
\end{tabular}


Fig. 3. Mean values of zooplankton quantitative and qualitative measures. Small square: average, rectangle: \pm standard error, "swirls": \pm SD.

Table 5. Similarity of zooplankton communities between individual reservoirs, based on Bray-Curtis dissimilarity index.

\begin{tabular}{llll}
\hline & $\mathrm{CH}$ & $\mathrm{KA}$ & $\mathrm{PN}$ \\
\hline $\mathrm{CH}$ & 0.000 & & \\
$\mathrm{KA}$ & 0.624 & 0.000 & \\
$\mathrm{PN}$ & 0.847 & 0.535 & 0.000 \\
\hline
\end{tabular}

medium-sized cladocerans (D. cucullata), in particular, depend on an appropriate density of plankton algae, which depends, in turn, on the productivity of the ecosystem (Beisner, 2001; Zurek, 2006). On the other hand, suspensions that reduce visibility protect zooplankton organisms, mostly larger species (e.g., Cladocera) from being attacked by fish feeding on plankton (Sutela and Huusko, 2000; Špoljar et al., 2011).

Particles of organic and mineral suspension are substrates for the growth of bacteria, which stimulates the mass growth of the rotifers that feed on these bacteria, e.g., Keratella spp. and F. longiseta (Mayer et al., 1997; Ejsmont-Karabin, 2012). Strong populations of these taxa were observed in reservoir $\mathrm{CH}$. However, their absence or the presence of single individuals were found in reservoir KA, and the general decrease in the number and diversity of Rotifera was most probably a consequence of the development of populations of D. cucullata and other cladocerans (Gilbert, 1988). Balvert et al. (2009) describe the complete elimination of rotifers subsequent to the mass occurrence of Daphnia dentifera in a post-mining pond.

Thermal-oxygen water conditions were closely correlated with zooplankton structure characteristics in reservoir PN (Figs. 4 and 5), where there was a distinctly low total number of zooplankton, and the species identified constituted weak populations with low numbers of individuals. The constant presence of rotifers of the genus Notholca was, however, noteworthy. The species Notholca acuminata and Notholca squamula are moderately psychrophilic stenothermic organisms that are found in temperate geographical latitudes in the early spring months in waters with temperatures below $10^{\circ} \mathrm{C}$ (Ejsmont-Karabin et al., 2004). In reservoir PN, these species were present throughout the study period, and when the water temperature was $18^{\circ} \mathrm{C}$, they achieved dominant status $(>5 \%)$. A similar pattern was observed in May (1980) in a shallow eutrophic lake where the presence of $N$. squamula, irrespective of the water temperature, depended on the constant availability of its preferred food, i.e., Asterionella formosa (Bacillariophyceae). The environment of reservoir PN was distinguished by an abundant assemblage of diatoms; there were numerous species of the order Pennales. Pociecha (2008) documents the effect of diatom food resources of a similar composition on the high number (over 100 ind. $\mathrm{L}^{-1}$ ) of Notholca squamula salina in a shallow Arctic lake in May and June.

Diatoms do not require high concentrations of nutrients in the water. They successfully competed for scant phosphorus resources in the waters of this reservoir and eliminated green algae, but they were not a completely available food for most species of plankton filter-feeders. The low primary production in reservoir PN was associated with the absence of phosphorus in the water. Aluminum originating from rock minerals and known under the common name aluminosilicates could simultaneously act as a carrier binding phosphorus from the water (de Vincente et al., 2008). The coagulation processes of silicates and metal hydroxides on the surface of sediments limited the life of phytoplankton. Considering how long reservoir PN has been in use and how important the time factor is for the advancement of coagulation processes, it is plausible that such distortions in the circulation of phosphorus compounds could have come into play (Goedcoop and Pettersson, 2000; de Vincente et al., 2008). In addition, silica compounds in the water and sediments of 




Fig. 4. Ordination biplot of redundancy analysis (RDA) for zooplankton communities (species) and hydrochemical data (environmental variables). Vectors pointing in the same direction indicate a positive correlation, vectors crossing at right angles indicate a near zero correlation, while vectors pointing in opposite direction show a high negative correlation. Abbreviations used in the figures: Asc_ova, Ascomorpha ovalis; Asp_pri, Asplanchna priodonta; Bos_lon, Bosmina longirosrtis; Bra_ang, Brachionus angularis; Bra_cal, Brachionus calyciflorus; cop, copepodite of cyclopoids; Dap_cuc, Daphnia cucullata; Fil lon, Filinia longiseta; Hex mir, Hexarthra mira; Ker_coc, Keratella cochlearis; Ker_tec, Keratella tecta; Ker_qua, Keratella quadrata; Ker_val, Keratella valga; nau, nauplii of cyclopoids; Not acu, Notholca acuminata; Not sqa, Notholca squamula; Pol_lon, Polyarthra longiremis; Pol_vul, Polyarthra vulgaris; Pom_sul, Pompholyx sulcata; Syn_spp., Synchaeta spp.; Tes_pat, Testudinella patina; The_cra, Thermocyclops crassus, Tri_sim, Trichocerca similis.

Table 6. Summary statistics for the first four axes of RDA of zooplankton data from analyzed reservoirs in June/July (spring/ summer season) and August/September (summer/autumn season) in 2012-2013.

\begin{tabular}{|c|c|c|c|c|c|}
\hline Axes & 1 & 2 & 3 & 4 & $\begin{array}{l}\text { Total } \\
\text { variance }\end{array}$ \\
\hline Eigenvalues & 0.449 & 0.164 & 0.107 & 0.061 & 1.000 \\
\hline Species-envir. correl & 0.946 & 0.988 & 0.966 & 0.947 & - \\
\hline \multirow{3}{*}{$\begin{array}{l}\text { Cumulative } \% \text { variance } \\
\text { of species data } \\
\text { of species-envir. relation }\end{array}$} & - & - & - & - & - \\
\hline & 44.9 & 61.3 & 71.9 & 78.0 & - \\
\hline & 51.8 & 70.6 & 82.9 & 90.0 & - \\
\hline Sum of all eigenvalues & - & - & - & - & 1.000 \\
\hline $\begin{array}{l}\text { Sum of all canonical } \\
\text { eigenvalues }\end{array}$ & - & - & - & - & 0.867 \\
\hline
\end{tabular}

reservoir PN (8-10\% higher than in reservoirs $\mathrm{CH}$ and $\mathrm{KA}$ ) contributed to the development of diatoms. The results published by Tilman et al. (1982) and van Donk and Kilham (1990) indicate that the preferred food of the rotifer genus Notholca - diatom Asterionella formosa develops in proportion to increasing ratios of Si:P in the water.

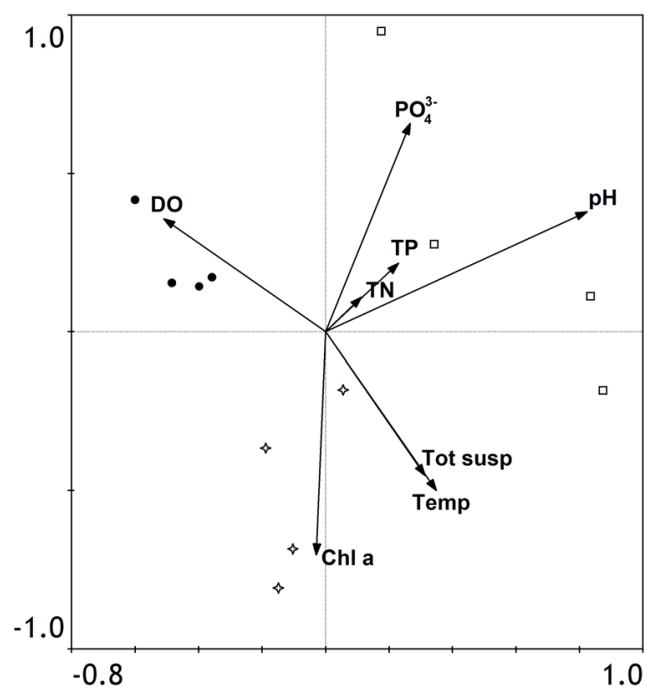

Fig. 5. RDA ordination plot of samples and environmental variables. Denotations: DO - dissolved oxygen, $\mathrm{Chl} a-$ chlorophyll $a$, TP total phosphorus, $\mathrm{TN}-$ total nitrogen, $\mathrm{PO}_{4}{ }^{3-}-$ orthophosphate, Tot susp - total suspension. Filled circle: $\mathrm{PN}$, open square: $\mathrm{CH}$, open star: KA.

\section{Summary}

The environment of the studied reservoirs provided good conditions for the development of rich communities of zooplankton. However, each of the reservoirs retained a certain separateness and characteristics of abiotic conditions that determined the structure of zooplankton. At this stage, it is difficult to assess which environment created the best conditions for the development and co-existence of the rich structure of zooplankton. The most clearly outlined aspects of the effects of abiotic factors on plankton biocenosis were analyzed. The eutrophy factor, just like in natural water ecosystems, determined good nutrition conditions and promoted the richness of zooplankton. On the other hand, the high concentration and composition of suspensions have limited these features. The above observations are an initiation to further analyzes directed to the functioning of zooplankton community under turbid water conditions. Apart from abiotic factors stated above, we cannot exclude the role of fish predation on zooplankton structure. Knowledge of the functioning of artificial reservoirs is just as important as that of natural lakes. While contributing to human needs, artificial reservoirs also fulfill important ecological functions.

Acknowledgments. This study was supported financially by the PGE Górnictwo i Energetyka Konwencjonalna SA Oddział KWB Bełchatów, agreement No. LPU/1225/2011 and by WFOS $\mathrm{iGW}$ in Łódź.

\section{References}

APHA. 1999. Standard methods for the examination of water and wastewater, 20th ed. Washington, DC: American Public Health Association. 
Balvert SF, Duggan IC, Hogg ID. 2009. Zooplankton seasonal dynamics in a recently filled mine pit lake: the effect of nonindigenous Daphnia establishment. Aquat Ecol 43: 403-413.

Beisner BE. 2001. Herbivory in variable environments: an experimental test of the effects of vertical mixing and Daphnia on phytoplankton community structure. Can J Fish Aquat Sci 58: 1371-1379.

Bian Z, Inyang HI, Daniels JL, Otto F, Struthers S. 2010. Environmental issues from coal mining and their solutions. Min Sci Technol 20: 0215-0223.

Bielańska-Grajner I, Cudak A. 2014. Effects of salinity on species diversity of Rotifers in anthropogenic water bodies. Pol J Environ Stud 23: 27-34.

Bielańska-Grajner I, Gładysz A. 2010. Planktonic rotifers in mining lakes in the Silesian Upland: relationship to environmental parameters. Limnologica 40: 67-72.

Bielańska-Grajner I, Cudak A, Biała A, Szymańczak R, Sell J. 2014. Role of spatial and environmental factors in shaping the rotifer metacommunity in anthropogenic water bodies. Limnology 15: 173-183.

Błędzki LA, Rybak JI. 2016. Freshwater crustacean zooplankton of Europe: Cladocera \& Copepoda (Calanoida, Cyclopoida). Key to species identification with notes on ecology, distribution, methods and introduction to data analysis. Springer, $918 \mathrm{p}$.

Boix D, Gascón S, Sala J, Badosa A, Brucet S, López-Flores R, Martinoy M, Gifre J, Quintana XD. 2008. Patterns of composition and species richness of crustaceans and aquatic insects along environmental gradients in Mediterranean water bodies. Hydrobiologia 597: 53-69.

Bottrell HH, Duncan A, Gliwicz ZM, Grygierek E, Herzig A, Hillbicht-Ilkowska A, Kurasawa H, Larsson P, Wegleńska T. 1976. A review of some problems in zooplankton production studies. Nor $J$ Zool 24: 419-456.

Carlson RE. 1977. A trophic state index for lakes. Limnol Oceanogr 22: 361-369.

de Vincente I, Jensen HS, Andersen FØ. 2008. Factors affecting phosphate adsorption to aluminum in lake water: implications for lake restoration. Sci Total Environ 389: 29-36.

Dodson SI, Arnott SE, Cottingham KL. 2000. The relationship in lake communities between primary productivity and species richness. Ecology 81: 2662-2679.

Dodson SI, Everhart WR, Jandl AK, Krauskopf SJ. 2007. Effect of watershed land use and lake age on zooplankton species richness. Hydrobiologia 579: 393-399.

Ejsmont-Karabin J. 1998. Empirical equations for biomass calculation of planktonic rotifers. Pol Arch Hydr 45: 513-522.

Ejsmont-Karabin J. 2012. The usefulness of zooplankton as lake ecosystem indicators: Rotifer trophic state index. Pol J Ecol 60: 339-350.

Ejsmont-Karabin J. 2013. An analysis based on rotifer indices of the effect of water and sewage management on the water quality in the system of interconnected glacial lakes. Limnol Rev 13: 191-195.

Ejsmont-Karabin J, Radwan S, Bielańska-Grajner I. 2004. Rotifers. Monogononta-atlas of species. Polish freshwater fauna. Łódź: Univ of Łódź, 447 p. (in Polish).

Ferrari CR, de Azevedo H, Wisniewski MJS, Rodgher S, Roque CV, Nascimento MRL. 2015. An overview of an acidic uranium mine pit lake (Caldas, Brazil): composition of the zooplankton community and limnochemical aspects. Mine Water Environ 34: 343-351.

Flössner D. 1972. Krebstiere, Crustacea. Kiemen-und Blattfüsser, Branchiopoda, Fischläuse, Branchiura. Jena: VEB Gustav Fischer Verlag, 382 p. (in German).
Gilbert JJ. 1988. Suppresion of rotifer populations by Daphnia, a review of the evidence, the mechanism and the effects on zooplankton community structure. Limnol Oceanogr 33: 12861303.

Goedcoop W, Pettersson K. 2000. Seasonal changes in sediments phosphorus forms in relation to sedimentation and benthic bacterial biomass in Lake Erken. Hydrobiologia 431: 41-50.

Goździejewska A, Tucholski S. 2011. Zooplankton of Fish Culture Ponds Periodically Fed with Treated Wastewater. Pol J Environ Stud 20: 67-79.

Goździejewska A, Glińska-Lewczuk K, Obolewski K, Grzybowski M, Kujawa R, Lew S, Grabowska M. 2016. Effects of lateral connectivity on zooplankton community structure in floodplain lakes. Hydrobiologia 774: 7-21.

Hammer UT. 1993. Zooplankton distribution and abundance in saline lakes of Alberta and Saskatchewan, Canada. Int J Salt Lake Res 2: 111.

Kasprzak K, Niedbała W. 1981. Biocenotic indices in quantitative study. In Górny M, Grüm L eds. Methods Applied in Soil Zoology. Warsaw: PWN, pp. 396-416.

Kerfoot WC, Sih A. 1987. Predation. Direct and Indirect Impacts on Aquatic communities. Hanover: University Press of New England, $160 \mathrm{p}$.

Koste W. 1978. Rotatoria. Die Rädertiere Mitteleuropas. Überordnung Monogononta. I Textband, II Tafelband. Berlin: Gebrüder Borntraeger, pp. 52-570. (in German).

Kovach WL. 2015. MVSP - a Multivariate statistical package for windows, ver. 3.2. Wales, U.K: Kovach Computing Services Pentraeth.

Kratzer CR, Brezonik PL. 1981. A Carlson-type trophic state index for nitrogen in Florida lakes. Water Res Bull 17: 713-715.

Lapčík V, Lapčíková M. 2011. Environmental impact assessment of surface mining. Inzynieria Mineralna. J Pol Mineral Eng Soc 1/6: $1-10$.

Mallo JC, De Marco SG, Bazzini SM, del Rio JL. 2010. Aquaculture: an alternative option for the rehabilitation of old mine pits in the Pampasian region, southeast of Buenos Aires, Argentina. Mine Water Environ 29: 285-293.

Marszelewski W, Dembowska E, Napiórkowski P, Solarczyk A. 2017. Understanding abiotic and biotic conditions in post-mining pit lakes for efficient management: a case study (Poland). Mine Water Environ 36: 418-428.

May L. 1980. On the ecology on the Notholca squamula Müller in Loch Leven, Kinross, Scotland. Hydrobiologia 73: 177-180.

Mayer J, Dokulil MT, Salbrechter M, Berger M, Posch T, Pfister G, Kirchner AK, Velimirov B, Steitz A, Ulbricht T. 1997. Seasonal successions and trophic relations between phytoplankton, zooplankton, ciliate and bacteria in a hypertrophic shallow lake in Vienna, Austria. Hydrobiologia 342/343: 165-174.

Merrix-Johnes FL, Thackeray SJ, Ormerod SJ. 2013. A global analysis of zooplankton in natural and artificial fresh waters. $J$ Limnol 72: 140-153.

Moser M, Weisse T. 2011. The most acidified Austrian lake in comparison to a neutralized mining lake. Limnologica 41: 303-315.

Nixdorf B, Lessmann D, Deneke R. 2005. Mining lakes in disturbed landscape: Apliccation of the EC Water Framework Directive and future management strategies. Ecol Eng 24: 67-73.

Pociecha A. 2008. Density dynamics of Notholca squamula salina Focke (Rotifera) in Lake Wujka, a freshwater Antarctic lake. Polar Biol 31: 275-279.

Pociecha A, Bielańska-Grajner I. 2015. Large-scale assessment of planktonic organisms biodiversity in artificial water reservoirs in Poland. IOP PAN, Kraków, 269 p. (in Polish). 
A.M. Goździejewska et al.: Knowl. Manag. Aquat. Ecosyst. 2018, 419, 33

Pociecha A, Bielańska-Grajner I, Szarek-Gwiazda E, Wilk-Woźniak E, Kuciel H, Walusiak E. 2017. Rotifer diversity in the acidic pyrite mine pit lakes in the Sudety Mountains (Poland). Mine Water Environ https://doi.org/10.1007/s10230-017-0492-y.

Rönicke H, Schultze M, Neumann V, Nitsche C, Tittel J. 2010. Changes of the plankton community composition during chemical neutralisation of the Bockwitz pit lake. Limnologica 40: 191-198.

Ruttner-Kolisko A. 1977. Suggestions for biomass calculation of planktonic rotifers. Arch Hydrobiol Beih Ergebn Limnol 8: 71-76.

Rybak JI, Błędzki LA. 2010. Freshwater planktonic crustaceans. Warsaw: Warsaw University Press, 307 p. (in Polish).

Rzętała M. 2008. Functioning of water reservoirs and the course of limnic processes under conditions of varied anthropopression a case study of Upper Silesian Region. Katowice: Silesian University Press, 165 p. (in Polish).

Sienkiewicz E, Gąsiorowski M. 2016. The evolution of a mining lake from acidity to natural neutralization. Sci Total Environ 557: 343-354.

Skowronek E, Cudak A, Bielańska-Grajner I. 2012. Effect of recreation on the species richness and diversity of rotifers in ponds. $J$ Water Res Prot 4: 795-799.

Sloss L. 2013. Coal mine site reclamation. Iea Clean Coal Centre, CCC/216 ISBN 978-92-9029-536-5, 70 p.

Špoljar M, Dražina T, Habdija I, Meseljević M, Grjčić Z. 2011. Contrasting zooplankton assemblages in two oxbow lakes with low transparencies and narrow emergent macrophyte belts (Krapina River, Croatia). Int Rev Hydrobiol 96: 175-190.
Stottmeister U, Mudroch A, Kennedy Ch, Matiova Z, Sanecki J, Svoboda I. 2002. Reclamation and regeneration of landscapes after brown coal opencast mining in six different countries. In Mudroch A et al., eds. Remediation of abandoned surface coal mining sites. Springer - Verlag Berlin Heidelberg, 33 p.

Sutela T, Huusko A. 2000. Varying resistance of zooplankton prey to digestion: implications for quantifying larval fish diets. Trans $\mathrm{Am}$ Fish Soc 129: 545-551.

ter Braak CJF, Šmilauer P. 2002. CANOCO reference manual and canodraw for windows user's guide: software for canonical community ordination (version 4.5). Ithaca, NY, (USA) (www. canoco.com): Microcomputer Power, 2002 p.

Tilman D, Kilham SS, Kilham P. 1982. Phytoplankton community ecology: the role of limiting nutrients. Annu Rev Ecol Syst 13: 349372.

van Donk E, Kilham SS. 1990. Temperature effects on silicon- and phosphorus-limited growth and competitive interactions among three diatoms. J Phycol 26: 40-50.

von Sperling E, Grandcham CAP. 2010. Formation of a deep pit lake: case study of Aguas Claras, Brasil. Int J Min Environ 1: $49-54$.

Younger PL, Wolkersdorfer CH. 2004. Mining impacts on the fresh water environment: technical and managerial guidelines for catchment scale management. Mine Water Environ 23: S2-S80.

Zurek R. 2006. Zooplankton of a flooded opencast sulphur mine. Aquat Ecol 40: 177-202.

Cite this article as: Goździejewska AM, Skrzypczak AR, Paturej E, Koszałka J. 2018. Zooplankton diversity of drainage system reservoirs at an opencast mine. Knowl. Manag. Aquat. Ecosyst., 419, 33. 